\title{
Agrarian potential of personal subsidiary plots
}

\author{
Kirill Zhichkin ${ }^{1, *}$, Vladimir Nosov ${ }^{2,3,4}$ and Lyudmila Zhichkina ${ }^{1}$ \\ ${ }^{1}$ Samara State Agrarian University, 446552, Kinel, Russia \\ ${ }^{2}$ K.G. Razumovsky Moscow State University of technologies and management, 109004, Moscow, Russia \\ ${ }^{3}$ Agrarian Technological Institute, Peoples' Friendship University, 117198, Moscow, Russia \\ ${ }^{4}$ Academy of the Investigative Committee of the Russian Federation, 125080, Moscow, Russia
}

\begin{abstract}
The article discusses the methodology for assessing the personal subsidiary plots production potential. Comparison of the private household plots efficiency is an important problem that requires early solution. It is the most promising direction for optimizing state support and stimulating production. The study purpose is to determine the territories of the Samara region that most effectively use the personal subsidiary plots resources for the agricultural production. The production potential value was the highest in the private household plots of the Samara region southern zone. On average, 1122.2 thousand rubles per hectare fall to personal subsidiary farms in one district of this zone. The production potential value is $36 \%$ lower in the Central (719.4 thousand rubles/ha) and by 56\% - in the Northern zone (493.0 thousand rubles/ha). The households of the Central natural-economic Zone most effectively use the production potential. The zonal average utilization rate value is 1.14 . The available resources are used in the best way by the personal subsidiary plots of the Bezenchuksky district $(\mathrm{Kp}=1.67)$, the worst - by the Sergievsky district (0.62). The considered methodology allows solving important problems - to assess the possibilities and the production real state in the private household plots sector.
\end{abstract}

\section{Introduction}

In Russian agriculture, as in a number of other countries' agricultural production, there is a special form of commodity producers - personal subsidiary plots [1-5]. Assessment of their efficiency, production volume and production potential is a rather difficult task due to their large number, small size, consumer nature and the lack of mandatory reporting [6-11]. At the same time, personal subsidiary plots play a significant role in providing agricultural products to the country population (Table 1). This applies to such industries as the production of milk and meat, potatoes, vegetables, fruits and berries. In other words, in those industries there is a significant proportion of manual labour and there are no industrial technologies [12-18].

Table 1. The share of personal subsidiary plots in the production of agricultural products in the Russian Federation, \%

\begin{tabular}{|c|c|c|c|c|c|c|}
\hline Product & 2000 & 2014 & 2015 & 2016 & 2017 & 2018 \\
\hline $\begin{array}{c}\text { Grain (in weight after } \\
\text { processing) }\end{array}$ & 0.8 & 0.9 & 0.9 & 0.9 & 0.8 & 0.8 \\
\hline Potatoes & 91.2 & 74.6 & 70.3 & 69.4 & 68.9 & 68.0 \\
\hline Vegetables & 74.7 & 63.8 & 59.9 & 58.6 & 55.4 & 55.1 \\
\hline $\begin{array}{c}\text { Livestock and poultry for } \\
\text { slaughter (slaughter weight) }\end{array}$ & 58.0 & 24.3 & 22.1 & 20.7 & 19.1 & 18.0 \\
\hline Milk & 50.9 & 45.8 & 44.0 & 42.1 & 40.2 & 38.7 \\
\hline Eggs & 28.8 & 21.2 & 20.5 & 19.7 & 18.8 & 18.5 \\
\hline Wool (in physical weight) & 56.8 & 49.1 & 49.1 & 47.3 & 47.2 & 46.5 \\
\hline Honey & 88.2 & 93.8 & 93.7 & 94.0 & 94.0 & 94.1 \\
\hline
\end{tabular}

\section{Materials and Methods}

To assess the state and production capabilities of personal subsidiary farms in the Samara region, we used the methods of grouping and regression analysis.

The grouping method allows determining the comparative size of production. The value of agricultural production per one villager is used as an estimated indicator. Median values, upper and lower quartiles were applied as the boundaries of the estimated intervals.

Regression analysis was used to calculate the production potential of personal subsidiary plots. Subsequently, the obtained values were compared with actual production volumes and the utilization rate of production potential (resources) was calculated. If this indicator exceeds one, it means that the personal

\footnotetext{
Corresponding author: zskirill@mail.ru
} 
subsidiary plots of a given area use the resources in question (labor, land, farm animals) in the best way.

\section{Results and discussion}

One of the most important parameters is the territorial distribution of private household plots relative to product markets, sources of non-agricultural employment [1922]. Based on the data for the Samara region, an analysis of the agricultural production by personal subsidiary plots in 2002, 2010 and 2018 was carried out. As a generalizing indicator, the indicator of agricultural production per 1 inhabitant of the municipal district was considered. In relation to the median value, all districts were grouped into 4 groups. The results are presented in Table 2. As can be seen from the analysis, the tendencies of production decline are typical for private subsidiary plots in almost all municipal districts of the region. The range of the indicator change is significantly expanded.
If in 2002 it was 10.3, 24.6; then in 2010 - 13.4, 52.5, and in $2018-19.5,77.0$ thousand rubles per person.

Considering the districts of the southern naturaleconomic zone of the Samara region, it is clear that the assumption made regarding the impact on the production level of the territorial distribution of districts is legitimate. The relative isolation of this territory forces the population to work more actively in private subsidiary plots. More than half of the districts in this zone belong to zones III and IV. At the same time, areas with a low level of production are located closer to cities that provide alternative employment (in industry, trade, services) (Fig. 1).

The situation is completely different in the region northern districts. During the analyzed period, there was a sharp decline in production in private household plots. If in 2002 only the Sergievsky district belonged to the I group (the main employment is the mining industry), then in 2018 there were already six districts out of nine I and II groups.

Table 2. Results of grouping municipal districts of Samara region.

\begin{tabular}{|c|c|c|c|}
\hline Group & 2002 & 2010 & 2018 \\
\hline $\begin{array}{l}\text { I (values to the } \\
\text { lower quartile) }\end{array}$ & $\begin{array}{c}\text { Bezenchuksky, Volzhsky, } \\
\text { Neftegorsky, Sergievsky, } \\
\text { Privolzhsky }\end{array}$ & $\begin{array}{l}\text { Bezenchuksky, Volzhsky, } \\
\text { Neftegorsky, Sergievsky }\end{array}$ & $\begin{array}{c}\text { Bezenchuksky, Volzhsky, } \\
\text { Neftegorsky, Sergievsky, } \\
\text { Kamyshlinsky, Klyavlinsky, Kinel- } \\
\text { Cherkassky, Shigonsky } \\
\end{array}$ \\
\hline $\begin{array}{l}\text { II (up to } \\
\text { median) }\end{array}$ & $\begin{array}{c}\text { Kinel-Cherkassky, Shigonsky, } \\
\text { Bogatovsky, Bolsheglushitsky, } \\
\text { Borsky, Krasnoyarsky }\end{array}$ & $\begin{array}{c}\text { Privolzhsky, Kamyshlinsky, } \\
\text { Klyavlinsky, Kinel-Cherkassky, } \\
\text { Shigonsky, Elkhovsky, Isaklinsky, } \\
\text { Bogatovsky, Bolsheglushitsky, } \\
\text { Borsky, Kinelsky, Krasnoyarsky, } \\
\text { Stavropolsky, Syzransky, } \\
\text { Pestravsky }\end{array}$ & $\begin{array}{c}\text { Privolzhsky, Elkhovsky, Isaklinsky, } \\
\text { Pohvistnevsky, Bogatovsky, } \\
\text { Bolsheglushitsky, Borsky, } \\
\text { Kinelsky, Krasnoyarsky, } \\
\text { Stavropolsky, Syzransky, } \\
\text { Pestravsky }\end{array}$ \\
\hline $\begin{array}{l}\text { III (above } \\
\text { median) }\end{array}$ & $\begin{array}{l}\text { Kamyshlinsky, Klyavlinsky, } \\
\text { Elkhovsky, Isaklinsky, } \\
\text { Pohvistnevsky, Koshkinsky, } \\
\text { Kinelsky, Stavropolsky, } \\
\text { Bolshechernigovsky, } \\
\text { Krasnoarmeysky, Pestravsky, } \\
\text { Khvorostyansky } \\
\end{array}$ & $\begin{array}{l}\text { Koshkinsky, Pohvistnevsky, } \\
\text { Chelno-Vershinsky }\end{array}$ & $\begin{array}{l}\text { Koshkinsky, Chelno-Vershinsky, } \\
\text { Krasnoarmeysky, Khvorostyansky }\end{array}$ \\
\hline $\begin{array}{c}\text { IV (values } \\
\text { above the upper } \\
\text { quartile) }\end{array}$ & $\begin{array}{c}\text { Chelno-Vershinsky, Syzransky, } \\
\text { Alekseevsky }\end{array}$ & $\begin{array}{l}\text { Alekseevsky, Bolshechernigovsky, } \\
\text { Krasnoarmeysky, Khvorostyansky }\end{array}$ & Alekseevsky, Bolshechernigovsky \\
\hline
\end{tabular}

The results of the grouping show that the approach to the zoning of personal subsidiary plots should differ from the territorial distribution principles of other production forms.

Their definition is an important problem that requires an early solution. It is the differentiation of state support for private household plots, taking into account their territorial location that is the most promising direction for optimizing state support and stimulating production in the households sector.

The purpose of further research was to determine the size of the personal subsidiary plots production potential to identify differences in the districts of the Samara region. Production potential is understood as the actual volume of products that will be produced at a given level of resources [23-29].

The production potential of agricultural enterprises is formed at the expense of four main sources: soil quality of agricultural land, expressed in bonitet points; availability of basic production assets (capital supply); available resources (material security) and labor resources [30-33]. Based on the constructed regression equation, it was revealed that these parameters explain the formation of agricultural potential by $96 \%$.

The reporting features of personal subsidiary plots do not allow for accurate accounting and measurement of all four identified factors. Therefore, it is proposed to use two as a basis, adding to them the third - the quality of soils, the availability of labor resources and the conditional livestock of farm animals (Table 3). These three factors comprehensively characterize the possibilities of private household plots in each district, showing the available amount of labor, describing the land use of households (with approximately equal plots, it is the quality of land plots that becomes important, expressed in points of soil bonitet) and animal husbandry, the condition of which is described in the number of conditional livestock. 


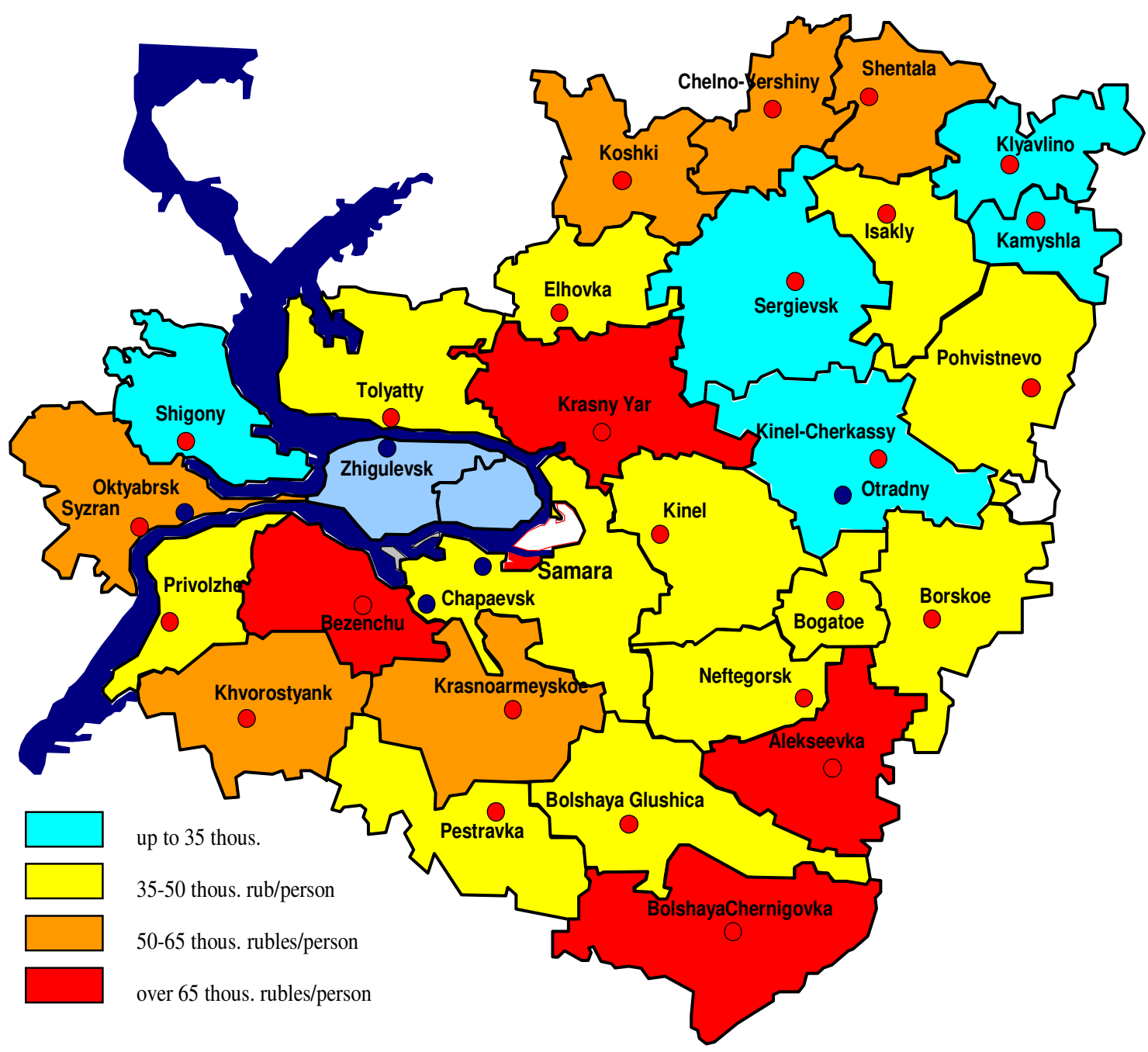

Fig. 1. Produced agricultural products of private household plots, 2018 (per one villager)

The production potential reflects the objective capabilities of personal subsidiary plots for the agricultural production. Identical conditions within natural-economic zones, uniform production technologies allow comparing the results of the activity of private household plots in the districts.

As an effective factor, it is proposed to use the gross production of personal subsidiary plots per 1 hectare of sown area (Table 4).

As a result of the analysis, a regression equation was drawn up, reflecting the formation of the agrarian production potential of personal subsidiary farms:

$$
Y=730.9+0.031 x_{1}-14.998 x_{2}+124.447 x_{3},
$$

where $Y$ - gross production of district private household plots per 1 ha of agricultural land, thousand rubles/ha; $x_{I}$ - availability of labor resources, people/ thousand ha; $x_{2}$ - average soil bonitet for the municipal district, point; $x_{3}$ - conditional livestock of farm animals, thousand conv. heads.

The value of the multiple correlation coefficient was 0.9 , which indicates a close relationship between the signs. The determination coefficient value is 0.82 .
On the basis of the obtained regression equation, the values of the personal subsidiary farms production potential in the Samara region districts and the coefficient of its use were calculated. The data are shown in Table 5.

The value of the production potential was the highest in the private household plots of the southern zone of Samara region. On average, 1122.2 thousand rubles per hectare fall to personal subsidiary farms in one district of this zone. The value of production potential is $36 \%$ lower in the Central (719.4 thousand rubles/ha) and by $56 \%$ - in the Northern zone (493.0 thousand rubles/ha).

At the same time, the production potential is most effectively used by the households of the Central naturaleconomic zone. Here the value of the zonal average utilization rate of production potential is 1.14. The available resources are used in the best way by the personal subsidiary plots of the Bezenchuksky district $(\mathrm{Kp}=1.67)$, the worst - by the Sergievsky district $(0.62)$.

\footnotetext{
* Corresponding author: zskirill@mail.ru
} 
Table 3. The production potential resource base of the Samara region personal subsidiary plots.

\begin{tabular}{|c|c|c|c|c|c|c|c|c|}
\hline \multirow[b]{2}{*}{$\begin{array}{l}\text { Natural } \\
\text { econom } \\
\text { ic zone }\end{array}$} & \multirow[b]{2}{*}{ District } & \multicolumn{2}{|c|}{ Soil quality } & \multicolumn{2}{|c|}{$\begin{array}{l}\text { Provision with } \\
\text { labor resources }\end{array}$} & \multicolumn{2}{|c|}{$\begin{array}{l}\text { Conditional livestock of } \\
\text { farm animals }\end{array}$} & \multirow{2}{*}{$\begin{array}{l}\text { Aggregate } \\
\text { resource } \\
\text { endowment } \\
\text { index }\end{array}$} \\
\hline & & ठัٌ & 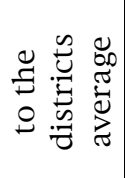 & 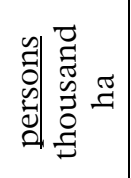 & 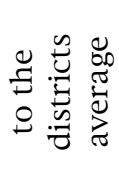 & 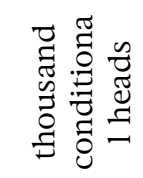 & 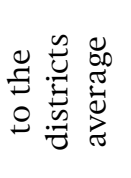 & \\
\hline \multirow{9}{*}{ 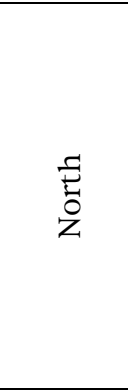 } & Elkhovsky & 63 & 0.99 & 9910 & 0.66 & 2.11 & 0.52 & 0.72 \\
\hline & Isaklinsky & 64 & 1.01 & 8536 & 0.57 & 2.85 & 0.70 & 0.76 \\
\hline & Kamyshlinsky & 64 & 1.01 & 12252 & 0.81 & 1.86 & 0.46 & 0.76 \\
\hline & Klyavlinsky & 61 & 0.96 & 9928 & 0.66 & 2.38 & 0.59 & 0.74 \\
\hline & Koshkinsky & 74 & 1.17 & 9219 & 0.61 & 5.93 & 1.47 & 1.08 \\
\hline & Pohvistnevsky & 70 & 1.10 & 6462 & 0.43 & 4.06 & 1.00 & 0.84 \\
\hline & Sergievsky & 64 & 1.01 & 19289 & 1.28 & 4.25 & 1.05 & 1.11 \\
\hline & $\begin{array}{l}\text { Chelno- } \\
\text { Vershinsky }\end{array}$ & 74 & 1.17 & 9257 & 0.61 & 5.37 & 1.33 & 1.04 \\
\hline & Shentalinsky & 68 & 1.07 & 5080 & 0.34 & 4.13 & 1.02 & 0.81 \\
\hline \multirow{11}{*}{ 苛 } & Bezenchuksky & 64 & 1.01 & 12099 & 0.80 & 3.74 & 0.92 & 0.91 \\
\hline & Bogatovsky & 66 & 1.04 & 7732 & 0.51 & 2.51 & 0.62 & 0.72 \\
\hline & Borsky & 63 & 0.99 & 13110 & 0.87 & 3.88 & 0.96 & 0.94 \\
\hline & Volzhsky & 67 & 1.05 & 24841 & 1.65 & 4.49 & 1.11 & 1.27 \\
\hline & Kinelsky & 67 & 1.05 & 18113 & 1.20 & 4.1 & 1.01 & 1.09 \\
\hline & Kinel-Cherkassky & 67 & 1.05 & 18139 & 1.20 & 4.62 & 1.14 & 1.13 \\
\hline & Krasnoyarsky & 64 & 1.01 & 15445 & 1.03 & 4.04 & 1.00 & 1.01 \\
\hline & Privolzhsky & 65 & 1.02 & 26919 & 1.79 & 5.45 & 1.35 & 1.39 \\
\hline & Stavropolsky & 77 & 1.21 & 15716 & 1.04 & 4.81 & 1.19 & 1.15 \\
\hline & Syzransky & 60 & 0.94 & 12055 & 0.80 & 3.34 & 0.83 & 0.86 \\
\hline & Shigonsky & 61 & 0.96 & 8482 & 0.56 & 1.89 & 0.47 & 0.66 \\
\hline \multirow{8}{*}{$\underset{D}{己}$} & Alekseevsky & 54 & 0.85 & 10940 & 0.73 & 4.38 & 1.08 & 0.89 \\
\hline & Bolsheglushitsky & 55 & 0.87 & 39391 & 2.62 & 4.4 & 1.09 & 1.53 \\
\hline & $\begin{array}{l}\text { Bolshechernigov } \\
\text { sky }\end{array}$ & 52 & 0.82 & 30823 & 2.05 & 9.2 & 2.27 & 1.71 \\
\hline & Krasnoarmeysky & 60 & 0.94 & 17728 & 1.18 & 4.03 & 1.00 & 1.04 \\
\hline & Neftegorsky & 58 & 0.91 & 15529 & 1.03 & 2.38 & 0.59 & 0.84 \\
\hline & Pestravsky & 55 & 0.87 & 15274 & 1.01 & 3.84 & 0.95 & 0.94 \\
\hline & Khvorostyansky & 58 & 0.91 & 14161 & 0.94 & 5.19 & 1.28 & 1.04 \\
\hline & $\begin{array}{l}\text { Average by } \\
\text { districts }\end{array}$ & 64 & 1.00 & 15053 & 1.00 & 4.05 & 1.00 & 1.00 \\
\hline
\end{tabular}

Table 4. The effectiveness of personal subsidiary plots activities in the Samara region.

\begin{tabular}{|c|l|c|c|}
\hline $\begin{array}{c}\text { Natural economic } \\
\text { zone }\end{array}$ & \multicolumn{1}{|c|}{ District } & $\begin{array}{c}\text { Gross production, thousand } \\
\text { rubles/ha }\end{array}$ & $\begin{array}{c}\text { Relation to the regional } \\
\text { average }\end{array}$ \\
\hline \multirow{4}{*}{} & Elkhovsky & 437.09 & 0.58 \\
\cline { 2 - 4 } & Isaklinsky & 399.74 & 0.53 \\
\cline { 2 - 4 } & Kamyshlinsky & 381.94 & 0.51 \\
\cline { 2 - 4 } & Klyavlinsky & 361.51 & 0.48 \\
\cline { 2 - 4 } & Koshkinsky & 491.06 & 0.65 \\
\cline { 2 - 4 } & Pohvistnevsky & 335.75 & 0.44 \\
\cline { 2 - 4 } & Sergievsky & 553.41 & 0.73 \\
\cline { 2 - 4 } & Chelno-Vershinsky & 584.19 & 0.77 \\
\cline { 2 - 4 } & Shentalinsky & 298.12 & 0.39 \\
\hline \multirow{5}{*}{} & Bezenchuksky & 1021.45 & 1.35 \\
\cline { 2 - 4 } & Bogatovsky & 407.54 & 0.54 \\
\cline { 2 - 4 } & Borsky & 526.69 & 0.70 \\
\cline { 2 - 4 } & Volzhsky & 1160.72 & 1.54 \\
\cline { 2 - 4 } & Kinelsky & 986.25 & 1.31 \\
\cline { 2 - 4 } & Kinel-Cherkassky & 554.36 & 0.73 \\
\cline { 2 - 4 } & Krasnoyarsky & 1298.67 & 1.72 \\
\cline { 2 - 4 } & Privolzhsky & 1282.07 & 1.70 \\
\hline
\end{tabular}

\footnotetext{
* Corresponding author: zskirill@mail.ru
} 


\begin{tabular}{|l|l|c|c|}
\hline & Stavropolsky & 689.24 & 0.91 \\
\cline { 2 - 4 } & Syzransky & 649.73 & 0.86 \\
\cline { 2 - 4 } & Shigonsky & 304.89 & 0.40 \\
\hline \multirow{4}{*}{} & Alekseevsky & 759.24 & 1.00 \\
\cline { 2 - 4 } & Bolsheglushitsky & 1558.65 & 2.06 \\
\cline { 2 - 4 } & Bolshechernigovsky & 2272.05 & 3.01 \\
\cline { 2 - 4 } & Krasnoarmeysky & 910.31 & 1.20 \\
\cline { 2 - 4 } & Neftegorsky & 724.05 & 0.96 \\
\cline { 2 - 4 } & Pestravsky & 615.35 & 0.81 \\
\cline { 2 - 4 } & Khvorostyansky & 835.19 & 1.11 \\
\hline & $\begin{array}{l}\text { Average by } \\
\text { districts }\end{array}$ & 755.53 & 1.00 \\
\hline
\end{tabular}

Table 5. Use of the personal subsidiary plots production potential in the Samara region.

\begin{tabular}{|c|c|c|c|c|}
\hline $\begin{array}{l}\text { Natural } \\
\text { economic } \\
\text { zone }\end{array}$ & District & $\begin{array}{l}\text { Production potential, } \\
\text { thousand rubles/ha }\end{array}$ & $\begin{array}{l}\text { Production potential } \\
\text { utilization factor }\left(K_{p}\right)\end{array}$ & $\begin{array}{l}\text { Mid-zone } \\
\quad \mathrm{KP}\end{array}$ \\
\hline \multirow{9}{*}{ 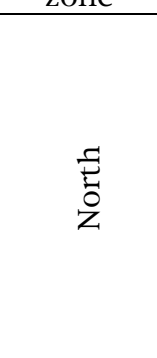 } & Elkhovsky & 355.83 & 1.23 & \multirow{9}{*}{0.91} \\
\hline & Isaklinsky & 390.32 & 1.02 & \\
\hline & Kamyshlinsky & 382.32 & 1.00 & \\
\hline & Klyavlinsky & 419.98 & 0.86 & \\
\hline & Koshkinsky & 644.83 & 0.76 & \\
\hline & Pohvistnevsky & 386.62 & 0.87 & \\
\hline & Sergievsky & 897.91 & 0.62 & \\
\hline & Chelno-Vershinsky & 576.30 & 1.01 & \\
\hline & Shentalinsky & 382.50 & 0.78 & \\
\hline \multirow{11}{*}{ 萢 } & Bezenchuksky & 611.53 & 1.67 & \multirow{11}{*}{1.14} \\
\hline & Bogatovsky & 293.10 & 1.39 & \\
\hline & Borsky & 675.30 & 0.78 & \\
\hline & Volzhsky & 1054.87 & 1.10 & \\
\hline & Kinelsky & 797.77 & 1.24 & \\
\hline & Kinel-Cherkassky & 863.29 & 0.64 & \\
\hline & Krasnoyarsky & 752.62 & 1.73 & \\
\hline & Privolzhsky & 1268.77 & 1.01 & \\
\hline & Stavropolsky & 661.84 & 1.04 & \\
\hline & Syzransky & 620.41 & 1.05 & \\
\hline & Shigonsky & 314.18 & 0.97 & \\
\hline \multirow{7}{*}{ 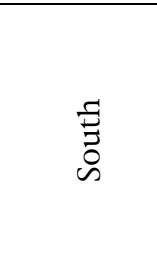 } & Alekseevsky & 805.24 & 0.94 & \multirow{7}{*}{0.96} \\
\hline & Bolsheglushitsky & 1674.72 & 0.93 & \\
\hline & Bolshechernigovsky & 2051.45 & 1.11 & \\
\hline & Krasnoarmeysky & 882.11 & 1.03 & \\
\hline & Neftegorsky & 638.60 & 1.13 & \\
\hline & Pestravsky & 857.41 & 0.72 & \\
\hline & Khvorostyansky & 945.91 & 0.88 & \\
\hline
\end{tabular}

\section{Conclusion}

The considered methodology allows us to solve an important problem - to assess the possibilities and the real state of production in the private household sector. This will provide government bodies with an information base in the event of expanding government support measures to household farms, and will help identify the most problematic areas that require attention in the first place.

\section{References}

1. I.A. Vladimirov, L.K. Rashitova, R.A. Iksanov, Studies in Systems, Decision and Control, 316, 777785 (2021). doi: 10.1007/978-3-030-57831-2_84

2. A. Lakomiak, K.A. Zhichkin, BIO Web of Conferences, 17, 00236 (2020). doi: 10.1051/bioconf/20201700236

3. S. Alpanda, S. Zubairy, European Economic $\begin{array}{lllll}\text { Review, 92, 47-73 (2017). doi: } & \end{array}$ 10.1016/j.euroecorev.2016.11.004

4. M.T. Tekueva, A.V. Burkov, V.V. Nosov, S.A. Novoselova, A.V. Nayanov, Research Journal of Pharmaceutical, Biological and Chemical Sciences, 7 (6), 1634-1638 (2016) 
5. D. Coen-Pirani, H. Sieg, Journal of Monetary Economics, 105, 44-71 (2019). doi: 10.1016/j.jmoneco.2019.04.001

6. E. G. Aleksandrova, V. A. Milyutkin, O. A. Blinova, BIO Web of Conferences, 17, 00040 (2020)

7. D. Morkovkin, I. Hutarava, E. Ogloblina, A. Gibadullin, S. Kharchenko, E3S Web of Conferences, 176, 05002 (2020)

8. D. French, S. Vigne, International Review of Financial Analysis, 62, 150-156 (2019). doi: 10.1016/j.irfa.2018.09.008

9. T.A. Isrigova, M.M. Salmanov, M.D. Mukailov, T.N. Ashurbekova, U.A. Selimova, Research Journal of Pharmaceutical, Biological and Chemical Sciences, 7(2), 2036-2043 (2016)

10. M. Jayasinghe, A. Chai, S. Ratnasiri, C. Smith, Food Policy, 73, 62-74 (2017). doi: 10.1016/j.foodpol.2017.09.005

11. S. Khayrzoda, D. Morkovkin, A. Gibadullin, O. Elina, E. Kolchina, E3S Web of Conferences, 176, 05007 (2020)

12. E. M. Akhmetshin, A. V. Pavlyuk, A. S. Kokorev et al., Journal of Applied Economic Sciences, 13(8)(62), 2309-2322 (2018)

13. N. Turdaliev, Y. Zhang, Economic Modelling, 77, 234-252 (2019). doi: 10.1016/j.econmod.2018.09.001

14. M.Y. Markin, E.I. Chefanova, Monitoring Obshchestvennogo Mneniya: Ekonomicheskie i Sotsial'nye Peremeny, 5, 112-129 (2020). doi: 10.14515/MONITORING.2020.5.532

15. O.P. Fadeeva, Regional Research of Russia, 10 (4), 562-573 (2020). doi: 10.1134/S2079970520040024

16. G. Shinet, B. Myrzaliyev, S. Ydyrys, Journal of Advanced Research in Law and Economics, 7 (2), 350-362 (2016). doi: 10.14505/jarle.v7.2(16).19

17. C. Southworth, Rural Sociology, 71 (3), 451-478 (2006). doi: 10.1526/003601106778070671

18. N.V. Zubarevich, Regional Research of Russia, 3 (3), 221-233 (2013). doi: 10.1134/S2079970513030118

19. T.G. Nefedova, Regional Research of Russia, 2 (1), 41-54 (2012). doi: 10.1134/S2079970512010078
20. E.B. Kuznetsova, O.V. Pratchenko, Mediterranean Journal of Social Sciences, 6 (3), 751-755 (2015). doi: 10.5901/mjss.2015.v6n3p751

21. I.Y. Sklyarov, Y.M. Sklyarova, Middle East Journal of Scientific Research, 17 (4), 424-428 (2013). doi: 10.5829/idosi.mejsr.2013.17.04.12193

22. M.S. Wortman, Agribusiness, 6 (4), 329-344 (1990)

23. S. O'Hara, M. Gentile, Eurasian Geography and Economics, 50 (3), 327-347 (2009). doi: 10.2747/1539-7216.50.3.327

24. R. Kapelyushnikov, Voprosy Ekonomiki, 7, 99-120 (2005). doi: 10.32609/0042-8736-2005-7-99-120

25. K.A. Zhichkin, V.V. Nosov, L.N. Zhichkina, A.V. Pavlyukova, L.N. Korobova, IOP Conference Series: Earth and Environmental Science, 659, 012005 (2021). doi:10.1088/1755$1315 / 659 / 1 / 012005$

26. J. Pallot, T. Nefedova, Eurasian Geography and Economics, 44 (1), 40-64 (2003)

27. M. Amelina, Post-Soviet Geography and Economics, 41 (7), 483-511 (2000). doi: 10.1080/10889388.2000.10641154

28. Yu. N. Kudryashova, T. G. Lazareva, T. N. Makushina, Yu. V. Chernova, BIO Web of Conferences, 17, 00028 (2020)

29. P. Caskie, Journal of Agricultural Economics, 51 (2), 196-209 (2000). doi: 10.1111/j.14779552.2000.tb01223.x

30. V. Nosov, A. Tcypin, S. Halasova, S. Zveryaeva, T. Shel, Proceedings of the 35th International Business Information Management Association (IBIMA): Education Excellence and Innovation Management: A 2025 Vision to Sustain Economic Development during Global Challenge 2207-2014 (2020)

31. G. Kitching, Journal of Peasant Studies, 26 (1), 43 81 (1998). doi: 10.1080/03066159808438694

32. H.T. Seeth, S. Chachnov, A. Surinov, J. Von Braun, World Development, 26 (9), 1611-1624 (1998). doi: 10.1016/S0305-750X(98)00083-7

33. T.A. Baimisheva, I.S. Kurmaeva, Y.Y. Gazizyanova, R.H. Baimeshev, G.A. Aiesheva, IOP Conference Series: Earth and Environmental Science, 315, 022090 (2019). doi: 10.1088/1755$1315 / 315 / 2 / 022090$ 